\title{
Non-Invasive Positive Pressure Ventilation (NIPPV) in the Pregnant Patient: A Case Series
}

\author{
Carlos Montufar-Rueda ${ }^{1}$, Agnès Ditisheim ${ }^{2}$, Alfredo F. Gei ${ }^{3}$, Rolando Pinilla1, Eddie Dinh ${ }^{3}$, \\ Jair Vélez ${ }^{3}$, Brenda Castillo ${ }^{3}$, Luis Farias ${ }^{3}$ \\ ${ }^{1}$ Critical Care Obstetrics Unit, Complejo Hospitalario Metropolitano de la Caja de Seguro Social, Ciudad de Panamá, Panamá \\ ${ }^{2}$ Center for Maternal-Fetal Medicine, La Tour Hospital, Geneva, Switzerland \\ ${ }^{3}$ Research Division, Houston Center for Maternal Fetal Medicine, Houston, Texas, USA \\ Email: *monlat2002@yahoo.com
}

How to cite this paper: Montufar-Rueda, C. Ditisheim, A., Gei, A.F., Pinilla, R., Dinh, E., Vélez, J., Castillo, B. and Farias, L. (2020) Non-Invasive Positive Pressure Ventilation (NIPPV) in the Pregnant Patient: A Case Series. Open Journal of Obstetrics and Gynecology, 10, 1563-1572.

https://doi.org/10.4236/ojog.2020.10110140

Received: October 1, 2020

Accepted: November 13, 2020

Published: November 16, 2020

Copyright (c) 2020 by author(s) and Scientific Research Publishing Inc. This work is licensed under the Creative Commons Attribution International License (CC BY 4.0).

http://creativecommons.org/licenses/by/4.0/

\begin{abstract}
Rationale: Acute respiratory failure is an uncommon complication of pregnancy. However, it is the most frequent organ dysfunction associated with obstetric admissions to an intensive care unit. The obstetric population is a different group due to its physiology and the presence of the fetus that lacks evidence in the literature within the subject of ventilatory support. Noninvasive positive pressure ventilation (NIPPV) is often avoided due to the lack of knowledge on the safety and efficacy of this modality. Currently, there are no guidelines for the management of respiratory failure in pregnancy. Objectives: To provide evidence in support of the use of NIPPV as a safe and reasonable modality for pregnant patients with respiratory failure. Methods: We retrospectively reviewed medical records of 29 pregnant patients of the Obstetric Critical Care Unit of a tertiary hospital in Panamá City who received NIPPV from 2013 to 2015. Failure to response was defined as the lack of increase in the $\mathrm{paO}_{2} / \mathrm{FiO}_{2}$ ratio or clinical deterioration 6 hours after initiating NIPPV. Demographics, indication for NIPPV, duration of treatment, as well as maternal and fetal outcomes were collected. Measurements and Main Results: Mean age was $28.4 \pm 6$ years, mean body mass index $27.4 \pm 3.3$, and mean gestational age at admission was $30^{5 / 7} \pm 5$ weeks. Twenty-four patients $(82.8 \%)$ met the criteria for acute lung injury (ALI) and an additional two (6.9\%) for acute respiratory distress syndrome (ARDS). The mean duration of ventilation was $50.6 \pm 17.27$ hours. Statistically significant differences were noted between the $\mathrm{paO}_{2} / \mathrm{FiO}_{2}$ ratios in failure and successful patients within 2 hours of NIPPV therapy $(\mathrm{P}=0.007)$ and $\mathrm{paO}_{2} / \mathrm{FiO}_{2}$ ratio within 6 hours of NIPPV therapy $(P=0.03)$. Success was defined when the patient was administered NIPPV, resulting in an improvement (increase in $\mathrm{pa} / \mathrm{FiO}_{2}$ ratio) of her ventilatory parameters. Three patients $(10.3 \%)$ failed to respond to
\end{abstract}


NIPPV and needed to be converted to invasive mechanical ventilation. $\mathrm{Pa}$ tients who required intubation had a longer duration of ICU stay $(P=0.006)$ and overall hospital stay $(\mathrm{P}=0.03)$. None of patients presented aspiration during NIPPV therapy. Conclusion: The current series is the largest report of pregnant patients requiring ventilatory support who received NIPPV as first line of therapy. This report shows the usefulness of this ventilation modality, avoiding intubation with its risks, of a significant number of patients, especially ventilator-associated pneumonia.

\section{Keywords}

Respiratory Support during Pregnancy, ARDS in Pregnancy, ALI in

Pregnancy, Ventilatory Support, Non-Invasive Positive Pressure Ventilation

\section{Introduction}

Acute respiratory failure $(\mathrm{ARF})$ is an uncommon but serious condition during pregnancy, complicating $0.1 \%$ to $0.2 \%$ of pregnancies, more commonly in the postpartum period [1]. It is one of the most frequent non-obstetric cause and the most common organ dysfunction associated with obstetric admissions to an intensive care unit (ICU) [2] [3] [4] [5].

Acute lung injury (ALI) and acute respiratory distress syndrome (ARDS) are two important causes of acute respiratory distress. Unfortunately, there is no evidence to guide the management of these conditions during pregnancy and current literature on the subject consists mainly of case reports and case series based on a small number.

Originally developed for chronic respiratory failure, the use of non-invasive positive pressure ventilation (NIPPV) for acute respiratory failure has increased considerably over the past decades and became a first line therapy for some indications [6] [7] [8].

The main concern for using NIPPV in pregnancy is a theoretical increased risk of pulmonary aspiration of gastric contents [9] [10]. Endotracheal intubation carries a risk of failed intubation up to 8 times greater in the pregnant cohort due to airway changes including edema and hyperemia [11] [12] [13]. Recent studies have recognized NIPPV as an ideal modality for the management of obstetric respiratory complications avoiding the risks of endotracheal intubation and ICU length of stay [1] [9] [14].

We decided to report a case series of acute respiratory failure during pregnancy managed with NIPPV as the first line of therapy.

\section{Methods}

We retrospectively reviewed the medical records of pregnant patient of the $\mathrm{Ob}$ stetric Critical Care Unit of a tertiary hospital in Panamá City, (Complejo Hospitalario de la Caja de Seguro Social, Panamá), who received non-invasive posi- 
tive pressure ventilation from 2013 to 2015. The research protocol and a standardized data extraction form were elaborated by members of the Multinational Consortium for Research in Critical Care Obstetrics (MCRCCOB) and available on a web-platform interface (www.mcrccob.org). Demographics, indication for NIPPV and duration of treatment, maternal and fetal outcomes were collected and reported on the web-platform.

Respiratory parameters were evaluated through arterial blood gases measurements performed before initiation of NIPPV. A $\mathrm{paO}_{2} / \mathrm{FiO}_{2}$ ratio was calculated before initiation of NIPPV, and after 2 and 6 hours of therapy to evaluate the response to NIPPV. Failure to response was defined as the lack of increase in the $\mathrm{paO}_{2} / \mathrm{FiO}_{2}$ ratio or clinical deterioration 6 hours after initiating NIPPV. The occurrence of aspiration and the need to convert to invasive ventilation were also documented, as well as the use of vasopressors. Neonatal outcome was evaluated by the Apgar score, NICU admission, duration of stay and neonatal death. This study was approved by the Ethic Committee of the institution and the need for the patient consent was waived for this retrospective study.

Data are expressed in mean (standard deviation) and in percentage (absolute number). Differences between groups of patients with failure and successful NIPPV therapy were evaluated with Chi square, Fisher exact test, Student's t test and Wilcoxon rank-sum as appropriate. A p value $<0.05$ was considered statistically significant. All data analysis was performed with Stata software, version 12.1 (College Station; Texas).

\section{Results}

Data from 29 patients admitted to the Obstetric Critical Care Unit between 2013 and 2015 was collected. Characteristics of the cohort are shown in Table 1 and Table 2. The maternal mean age was $28.4 \pm 6.0$ years with mean body mass index of $27.4 \pm 3.3 \mathrm{~kg} / \mathrm{m}^{2}$. The mean gestational age at admission was $30.7 \pm 5.7$ weeks. Eight women (27.5\%) delivered while on ventilatory support; four $(13.7 \%)$ of which were spontaneous labor and the other four $(13.7 \%)$ were induced for preeclampsia with severe features. All other women delivered after being discharged from the ICU. Mean gestational age at delivery was $33.1 \pm 4.9$ weeks. There were no maternal deaths.

Respiratory and ventilatory characteristics of the cohort are summarized in Table 3. The two main conditions leading to acute respiratory failure were pneumonia and extrapulmonary sepsis. Twenty-four patients $(82.8 \%)$ met the criteria for ALI and two additional patients (6.9\%) met criteria for ARDS. All patients received ventilation in the bilevel positive airway pressure mode (BiPAP), with a full-face mask. Inspiratory positive airway pressure (IPAP) settings ranged from $14-16 \mathrm{cmH}_{2} \mathrm{O}$, expiratory positive airway pressure (EPAP) ranges from $8-10 \mathrm{cmH}_{2} \mathrm{O}$ and the fraction of $\mathrm{O}_{2}$ percentage from $40 \%-100 \%$, according to the clinical response to NIPPV. The mean duration of ventilation was 50.6 \pm 17.2 hours at the term. Three patients $(10.3 \%)$ failed to respond to NIPPV and needed to be converted to invasive mechanical ventilation (Figure 1). 
Table 1. Non-invasive positive pressure ventilation in pregnancy. Characteristics of the cohort.

\begin{tabular}{|c|c|}
\hline Demographics & \\
\hline Age (years) & $28.4 \pm 6.0$ \\
\hline Gestational age at admission (weeks) & $30^{5 / 7} \pm 5$ \\
\hline Body mass index $\left(\mathrm{kg} / \mathrm{m}^{2}\right)$ & $27.4 \pm 3.3$ \\
\hline \multicolumn{2}{|l|}{ Condition leading to acute respiratory failure } \\
\hline \multicolumn{2}{|l|}{ Obstetric } \\
\hline Severe preeclampsia & $4(13.8 \%)$ \\
\hline Post-partum hemorrhage & $1(3.4 \%)$ \\
\hline \multicolumn{2}{|l|}{ Non-obstetric } \\
\hline Septic shock & $10(34.5 \%)$ \\
\hline Pneumonia & $8(27.6 \%)$ \\
\hline Acute chest syndrome & $3(10.3 \%)$ \\
\hline Cardiac failure & $2(6.9 \%)$ \\
\hline Asthma & $1(3.4 \%)$ \\
\hline \multicolumn{2}{|l|}{ Pregnancy outcome $\left(^{*}\right)$} \\
\hline Delivery during ICU stay & $8(27.6 \%)$ \\
\hline Gestational age at delivery & $33 \pm 4$ \\
\hline Cesarean section & $5(62.5 \%)$ \\
\hline Spontaneous labor & $4(50 \%)$ \\
\hline
\end{tabular}

Data are expressed in mean \pm standard deviation or absolute numbers (percentage); $\left({ }^{*}\right)$ Limited to patients who delivered during maternal ICU admission.

Table 2. Non-invasive positive pressure ventilation in pregnancy. Patient's characteristics at admission and after NIPPV therapy.

\begin{tabular}{|c|c|c|c|c|c|c|c|c|c|c|c|}
\hline $\begin{array}{l}\text { Patient } \\
\text { number }\end{array}$ & Age & $\begin{array}{l}\text { Gestational } \\
\text { age }\end{array}$ & Condition & Vasopressor & $\mathrm{sPO}_{2}$ & $\mathrm{paO}_{2}$ & $\mathrm{paCO}_{2}$ & $\mathrm{paO}_{2} / \mathrm{FiO}_{2}$ & $\begin{array}{c}\mathrm{paO}_{2} / \mathrm{FiO}_{2} \\
\text { (within } \\
2 \mathrm{hrs} \text { ) }\end{array}$ & $\begin{array}{c}\text { Duration } \\
\text { of NPPV } \\
\text { (hrs) }\end{array}$ & $\begin{array}{c}\text { Conversion } \\
\text { to mechanical } \\
\text { ventilation }\end{array}$ \\
\hline 1 & 25 & 33 & $\begin{array}{l}\text { Septic shock of } \\
\text { urinary source }\end{array}$ & Yes & 92 & 61 & 39 & 290 & 325 & 74 & No \\
\hline 2 & 32 & 285 & $\begin{array}{l}\text { Community } \\
\text { acquired pneumonia }\end{array}$ & Yes & 91 & 58 & 41 & 276 & 346 & 28 & No \\
\hline 3 & 28 & 32 & $\begin{array}{l}\text { Severe Preeclampsia } \\
\text { w/pulmonary edema }\end{array}$ & No & 92 & 68 & 38 & 226 & 240 & 47 & No \\
\hline 4 & 35 & 213 & $\begin{array}{c}\text { Community acquired } \\
\text { pneumonia }\end{array}$ & Yes & 90 & 59 & 42 & 280 & 350 & 39 & No \\
\hline 5 & 26 & 35 & $\begin{array}{l}\text { Sepsis on appendicitis } \\
\text { w/peritonitis }\end{array}$ & No & 90 & 60 & 38 & 285 & 320 & 36 & No \\
\hline 6 & 27 & 32 & $\begin{array}{l}\text { Septic shock of } \\
\text { urinary source }\end{array}$ & Yes & 78 & 62 & 36 & 295 & 340 & 42 & No \\
\hline 7 & 34 & 313 & $\begin{array}{c}\text { Community acquired } \\
\text { pneumonia }\end{array}$ & Yes & 88 & 63 & 39 & 300 & 425 & 40 & No \\
\hline 8 & 22 & 324 & $\begin{array}{l}\text { Acute chest syndrome } \\
\text { w/pneumonia }\end{array}$ & No & 91 & 68 & 45 & 323 & 340 & 48 & No \\
\hline
\end{tabular}




\section{Continued}

\begin{tabular}{|c|c|c|c|c|c|c|c|c|c|c|c|}
\hline 9 & 31 & 37 & $\begin{array}{l}\text { Severe Preeclampsia } \\
\text { w/pulmonary edema }\end{array}$ & No & 90 & 59 & 44 & 196 & 240 & 70 & Yes \\
\hline 10 & 38 & 384 & $\begin{array}{l}\text { Severe Preeclampsia } \\
\text { w/pulmonary edema }\end{array}$ & No & 87 & 62 & 38 & 295 & 280 & 96 & Yes \\
\hline 11 & 19 & 26 & $\begin{array}{l}\text { Severe sepsis of } \\
\text { urinary source }\end{array}$ & No & 92 & 64 & 40 & 304 & 320 & 70 & No \\
\hline 12 & 24 & 283 & $\begin{array}{l}\text { Community } \\
\text { acquired pneumonia }\end{array}$ & No & 90 & 60 & 36 & 285 & 350 & 48 & No \\
\hline 13 & 37 & 342 & $\begin{array}{c}\text { Acute chest syndrome } \\
\text { w/pneumonia }\end{array}$ & Yes & 89 & 61 & 42 & 290 & 350 & 52 & No \\
\hline 14 & 27 & 36 & $\begin{array}{c}\text { Septic shock on acute } \\
\text { cholecystitis }\end{array}$ & Yes & 88 & 62 & 39 & 295 & 450 & 45 & No \\
\hline 15 & 36 & 314 & $\begin{array}{l}\text { Septic shock on } \\
\text { pyelonephritis }\end{array}$ & Yes & 85 & 58 & 28 & 276 & 300 & 40 & No \\
\hline 16 & 24 & 31 & $\begin{array}{l}\text { Septic shock of } \\
\text { urinary origin }\end{array}$ & Yes & 91 & 58 & 43 & 276 & 320 & 45 & No \\
\hline 17 & 34 & 385 & $\begin{array}{l}\text { Pulmonary edema on } \\
\text { rheumatic mitral } \\
\text { valvular disease }\end{array}$ & No & 88 & 60 & 39 & 285 & 336 & 40 & No \\
\hline 18 & 36 & 34 & $\begin{array}{c}\text { Hypovolemic } \\
\text { shock/PPH }\end{array}$ & No & 91 & 58 & 42 & 276 & 340 & 48 & No \\
\hline 19 & 28 & 152 & H1N1 viral pneumonia & No & 91 & 60 & 40 & 240 & 340 & 50 & No \\
\hline 20 & 24 & 223 & $\begin{array}{c}\text { Community acquired } \\
\text { pneumonia }\end{array}$ & No & 90 & 59 & 39 & 280 & 360 & 45 & No \\
\hline 21 & 35 & 25 & $\begin{array}{l}\text { Acute decompensated } \\
\text { heart failure/dilated } \\
\text { myocardiopathy }\end{array}$ & No & 89 & 59 & 45 & 280 & 346 & 48 & No \\
\hline 22 & 25 & 31 & $\begin{array}{l}\text { Severe preeclampsia } \\
\text { w/pulmonary edema }\end{array}$ & No & 90 & 61 & 38 & 290 & 398 & 42 & No \\
\hline 23 & 36 & 26 & $\begin{array}{l}\text { Septic shock of } \\
\text { urinary origin }\end{array}$ & Yes & 88 & 60 & 36 & 285 & 380 & 48 & No \\
\hline 24 & 17 & 263 & $\begin{array}{l}\text { Acute Chest syndrome } \\
\text { w/pneumonia }\end{array}$ & No & 90 & 62 & 35 & 295 & 300 & 52 & No \\
\hline 25 & 18 & 34 & $\begin{array}{l}\text { Severe sepsis on } \\
\text { appendicitis }\end{array}$ & No & 84 & 58 & 40 & 276 & 360 & 72 & No \\
\hline 26 & 27 & 22 & $\begin{array}{l}\text { Severe asthma } \\
\text { w/pneumonia }\end{array}$ & No & 88 & 58 & 48 & 276 & 437 & 72 & No \\
\hline 27 & 32 & 346 & $\begin{array}{l}\text { Septic shock on } \\
\text { pyelonephritis }\end{array}$ & Yes & 90 & 74 & 27 & 185 & 148 & 6 & Yes \\
\hline 28 & 25 & 35 & $\begin{array}{c}\text { Community acquired } \\
\text { pneumonia }\end{array}$ & No & 90 & 59 & 32 & 280 & 450 & 50 & No \\
\hline 29 & 23 & 362 & $\begin{array}{l}\text { Community } \\
\text { acquired pneumonia }\end{array}$ & No & 88 & 58 & 31 & 276 & 380 & 73 & No \\
\hline
\end{tabular}




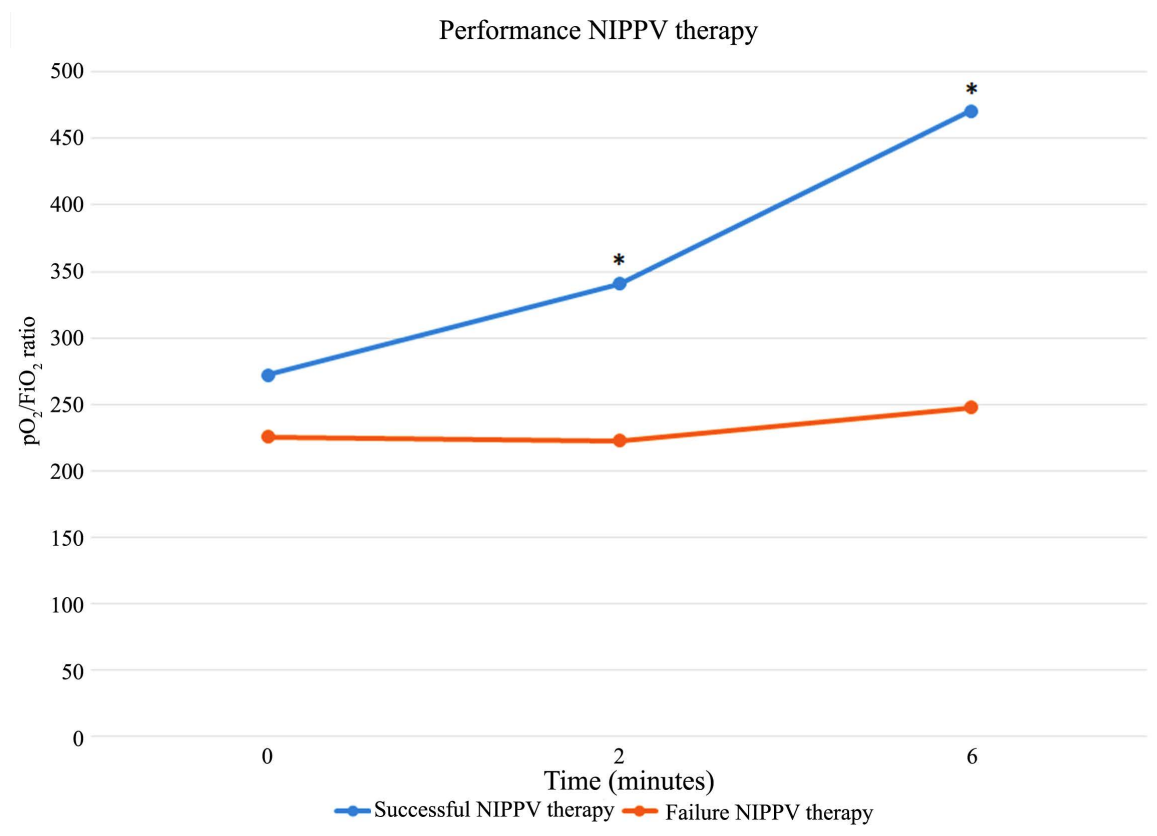

Figure 1. Non-invasive positive pressure ventilation in pregnancy. $\mathrm{paO}_{2} / \mathrm{FiO}_{2}$ ratio trends over time in successfully treated and failures. Legend: Statistically significant $\left.{ }^{*}\right)$ differences were noted at 2 hours and 6 hours of therapy.

Table 3. Non-invasive positive pressure ventilation in pregnancy. Respiratory and ventilatory characteristics of the cohort.

\begin{tabular}{cc}
\hline Severity of acute respiratory failure & \\
\hline Acute lung injury (ALI) & $24(82.8 \%)$ \\
Acute Respiratory Distress Syndrome (ARDS) & $2(6.9 \%)$ \\
$\mathrm{paO}_{2} / \mathrm{FiO}_{2}$ ratio at admission & $276.4 \pm 29.6$ \\
$\mathrm{Need}$ of vasopressor & $11(37.9 \%)$ \\
Ventilatory outcome & \\
Duration of ventilation (hours) & $50.6 \pm 17.2$ \\
Conversion to mechanical ventilation & $3(10.3 \%)$ \\
\hline
\end{tabular}

Data are expressed in mean \pm standard deviation or absolute number (percentage).

Statistically significant differences were noted between patients with successful and failed NIPPV therapy over time, in $\mathrm{paO}_{2} / \mathrm{FiO}_{2}$ ratio within 2 hours of NIPPV therapy $(\mathrm{P}=0.007)$ and $\mathrm{paO}_{2} / \mathrm{FiO}_{2}$ ratio within 6 hours of NIPPV therapy $(\mathrm{P}=0.03)$.

Correlation between $\mathrm{paO}_{2} / \mathrm{FiO}_{2}$ ratios in patients with successful and failed NIPPV therapy before initiation of NIPPV did not reach statistical significance.

Patients who required intubation had a longer duration of ICU stay $(\mathrm{P}=$ $0.006)$ and overall hospital stay $(P=0.03)$. None of the patients presented aspiration during NIPPV therapy.

Neonatal outcomes are shown in Table 4. The mean birthweight was $2002.5 \pm$ 1016 grams. 
Table 4. Non-invasive positive pressure ventilation in pregnancy. Neonatal outcomes $(\dagger)$.

\begin{tabular}{cc}
\hline $\begin{array}{c}\text { Mean birthweight (grams) } \\
\text { Apgar score }\end{array}$ & $2002.5 \pm 932$ \\
1 minute & $6.5(5-8)$ \\
5 minutes & $8(6-8)$ \\
NICU admission & $4(50 \%)$ \\
Neonatal morbidity & \\
Respiratory distress syndrome & $4(50 \%)$ \\
Jaundice & $2(25 \%)$ \\
Neonatal sepsis & $1(12.5 \%)$ \\
Neonatal death & $1(12.5 \%)$ \\
\hline
\end{tabular}

Data are expressed in mean \pm standard deviation, median (range) or absolute number (percentage). $(\dagger) \mathrm{Li}$ mited to neonates who were born during maternal ICU admission.

\section{Comment}

The pregnant state is a predisposition for the development of ARDS, with reported incidence rates higher than those found in the general population [9] [15] [16] [17].

In non-pregnant adults, the use of NIPPV has shown to be associated with a reduced rate of endotracheal intubation, lower rates for associated complications and overall ICU length of stay [18] [19]. Pregnancy has so far been considered a relative contraindication due to theoretical risk of aspiration. Aspiration in pregnancy can be associated with an increased intraabdominal pressure, reduced gastroesophageal sphincter tone and decreased gastric emptying due to the mechanical effects of the uterus and increased levels of progesterone [9] [10]. On the other hand, endotracheal intubation during pregnancy is associated with higher failure rates due to changes in the airway including edema and congestion [11] [12] [13]. Pregnant women are also more susceptible to desaturation due to the increased metabolic rate and the oxygen demands of the fetus [20].

Several case reports and small series have pointed out favorable outcomes for pregnant women who were managed with NIPPV for respiratory failure, while emphasizing the importance of patient selection [21] [22] [23].

Pregnant women are typically young, able to cooperate and otherwise healthy or lacking chronic cardio-pulmonary conditions that would require prolonged mechanical ventilatory support. Most of them will have intact dentition, leading to fewer air leak, and will present with a lower acuity of illness (APACHE score), with moderate hypercarbia and acidemia [24] [25]. Most conditions leading to respiratory failure in women (pulmonary edema due to preeclampsia, sepsis and asthma) are transient and expected to respond to medical treatment within 48 to 72 hours [20] [26]. These characteristics make pregnant women an attractive subset of patient to avoid the most common predictors of failure for NIPPV, which we speculate is the reason behind the high rates of success of this modality 
of ventilation in other reported series [27].

Of interest, in this study, the pregnant women $(\mathrm{n}=3 ; 10.3 \%)$ who required invasive mechanical ventilation developed ventilator-associated pneumonia (VAP). The immunity of pregnancy is known to affect the response to infectious agents and avoiding an invasion of their airway may be a strategic goal of initial ventilator support.

Failure of NIPPV could be detected within 2 hours based on clinical response and $\mathrm{paO}_{2} / \mathrm{FiO}_{2}$ ratios. This finding can potentially assist clinicians to make preparations for invasive mechanical ventilation well in advance to respiratory claudication.

The strengths of this study include its number and the variety of pathologies treated. The favorable response rate cannot be attributed to a "healthy population bias" since over $90 \%$ of them met accepted criteria for ALI or ARDS [28]. One limitation of this study is the missing pregnancy and neonatal outcomes of patients who were treated with NIPPV and were able to continue their pregnancies. Most of these women deliver in their communities of origin. This fact limits the conclusions that can be made regarding the fetal/neonatal safety and complications of this modality of ventilation. Based on the oxygenation response we speculate that NIPPV attenuated the potentially hypoxemic effects of the background condition and allowed for pregnancy continuation that would otherwise be impossible.

\section{Conclusions}

In conclusion, this case series adds to the existing evidence in favor of the successful application of NIPPV for the management of respiratory failure in carefully selected and closely monitored pregnant patients. In this cases report, we show that in case of deciding to install ventilatory support, it is possible to do it with the non-invasive mechanical ventilation modality (CPAP or BiPAP) without the dreaded risk of bronchoaspiration; in addition, it is possible to avoid endotracheal intubation with its infectious consequences (ventilator-associated pneumonia), or a poor outcome due to airway management in some patients.

We believe that further trials will determine guidelines for the appropriate use of NIPPV in pregnant women, optimal patient selection and safety profile particularly regarding maternal and fetal/neonatal outcomes.

\section{Conflicts of Interest}

None of the authors are reporting any conflict of interest.

\section{References}

[1] Lapinsky, S. (2015) Acute Respiratory Failure in Pregnancy. Obstetric Medicine, 8, 126-132. https://doi.org/10.1177/1753495X15589223

[2] Wanderer, J., Leffert, L., Mhyre, J., et al. (2013) Epidemiology of Obstetric-Related ICU Admissions in Maryland. Critical Care Medicine, 41, 1844-1852. https://doi.org/10.1097/CCM.0b013e31828a3e24 
[3] Vargas, M., Marra, A., Buonanno, P., et al. (2019) Obstetric Admissions in ICU in a Tertiary Care Center: A 5-Years Retrospective Study. Indian Journal of Critical Care Medicine, 23, 213-219.

[4] Mohammed, S., Bhatia, P., Biyani, G., et al. (2016) Acute Respiratory Failure and Mechanical Ventilation in Pregnant Patient: A Narrative Review of Literature. Journal of Anaesthesiology Clinical Pharmacology, 32, 431-439. https://doi.org/10.4103/0970-9185.194779

[5] Vasquez, D., Das Neves, A., Vidal, L., et al. (2015) Characteristics, Outcomes, and Predictability of Critically Ill Obstetric Patients. Critical Care Medicine, 43, 1887-1897. https://doi.org/10.1097/CCM.0000000000001139

[6] Rocker, G., Mackenzie, M., Williams, B., et al. (1999) Noninvasive Positive Pressure Ventilation. Chest, 115, 173-177. https://doi.org/10.1378/chest.115.1.173

[7] Keenan, S., Sinuff, T., Cook, D., et al. (2004) Does Noninvasive Positive Pressure Ventilation Improve Outcome in Acute Hypoxemic Respiratory Failure? A Systematic Review. Critical Care Medicine, 32, 2516-2523. https://doi.org/10.1097/01.CCM.0000148011.51681.E2

[8] Nava, S. and Hill, N. (2009) Non-Invasive Ventilation in Acute Respiratory Failure. The Lancet, 374, 250-259. https://doi.org/10.1016/S0140-6736(09)60496-7

[9] Cole, D., Taylor, T., McCullough, D., et al. (2005) Acute Respiratory Distress Syndrome in Pregnancy. Critical Care Medicine, 33, S269-S278. https://doi.org/10.1097/01.CCM.0000182478.14181.DA

[10] Lapinsky, S. (2017) Management of Acute Respiratory Failure in Pregnancy. Seminars in Respiratory and Critical Care Medicine, 38, 201-207. https://doi.org/10.1055/s-0037-1600909

[11] King, T. and Adams, A. (1991) Failed Tracheal Intubation. British Journal of Anaesthesia, 67, 225. https://doi.org/10.1093/bja/67.2.225-b

[12] Quinn, A., Milne, D., Columb, M., et al. (2013) Failed Tracheal Intubation in Obstetric Anaesthesia: 2 Yr National Case-Control Study in the UK. British Journal of Anaesthesia, 110, 74-80. https://doi.org/10.1093/bja/aes320

[13] Kinsella, S., Winton, A., Mushambi, M., et al. (2015) Failed Tracheal Intubation during Obstetric General Anaesthesia: A Literature Review. International Journal of Obstetric Anesthesia, 24, 356-374. https://doi.org/10.1016/j.ijoa.2015.06.008

[14] Mazlan, M., Ali, S., Zainal Abidin, H., et al. (2017) Non-Invasive Ventilation in a Pregnancy with Severe Pneumonia. Respiratory Medicine Case Reports, 21, 161-163. https://doi.org/10.1016/j.rmcr.2017.05.002

[15] Rush, B., Martinka, P., Kilb, B., et al. (2017) Acute Respiratory Distress Syndrome in Pregnant Women. Obstetrics \& Gynecology, 129, 530-535. https://doi.org/10.1097/AOG.0000000000001907

[16] Catanzarite, V., Willms, D., et al. (2001) Acute Respiratory Distress Syndrome in Pregnancy and the Puerperium: Causes, Courses, and Outcomes. Obstetrics \& Gynecology, 97, 760-764. https://doi.org/10.1097/00006250-200105000-00022

[17] Lapinsky, S. (2012) Pregnancy Joins the Hit List. Critical Care Medicine, 40, 1679-1680. https://doi.org/10.1097/CCM.0b013e3182474b11

[18] Schnell, D., Timsit, J., Darmon, M., et al. (2014) Noninvasive Mechanical Ventilation in Acute Respiratory Failure: Trends in Use and Outcomes. Intensive Care Medicine, 40, 582-591. https://doi.org/10.1007/s00134-014-3222-y

[19] Martin, T., Hovis, J., Costantino, J., et al. (2000) A Randomized, Prospective Evaluation of Noninvasive Ventilation for Acute Respiratory Failure. American Journal 
of Respiratory and Critical Care Medicine, 161, 807-813.

https://doi.org/10.1164/ajrccm.161.3.9808143

[20] Bandi, V., Munnur, U. and Matthay, M. (2004) Acute Lung Injury and Acute Respiratory Distress Syndrome in Pregnancy. Critical Care Clinics, 20, 577-607. https://doi.org/10.1016/j.ccc.2004.05.010

[21] Al-Ansari, M., Hameed, A., Al-jawder, S., et al. (2007) Use of Noninvasive Positive Pressure Ventilation during Pregnancy: Case Series. Annals of Thoracic Medicine, 2, 23-25. https://doi.org/10.4103/1817-1737.30358

[22] Bach, J. (2003) Successful Pregnancies for Ventilator Users. American Journal of Physical Medicine \& Rehabilitation, 82, 226-229. https://doi.org/10.1097/01.PHM.0000053395.41165.73

[23] Allred, C., Matias Esquinas, A., Caronia, J., et al. (2014) Successful Use of Noninvasive Ventilation in Pregnancy. European Respiratory Review, 23, 142-144. https://doi.org/10.1183/09059180.00008113

[24] Schwaiberger, D., Karcz, M., Menk, M., et al. (2016) Respiratory Failure and Mechanical Ventilation in the Pregnant Patient. Critical Care Clinics, 32, 85-95.

https://doi.org/10.1016/j.ccc.2015.08.001

[25] Mohammed, S., Bhatia, P., Biyani, G., et al. (2016) Acute Respiratory Failure and Mechanical Ventilation in Pregnant Patient: A Narrative Review of Literature. Journal of Anaesthesiology Clinical Pharmacology, 32, 431-439. https://doi.org/10.4103/0970-9185.194779

[26] Mighty, H. (2010) Acute Respiratory Failure in Pregnancy. Clinical Obstetrics and Gynecology, 53, 360-368. https://doi.org/10.1097/GRF.0b013e3181deb3f1

[27] Antonelli, M., Conti, G., Moro, M., et al. (2001) Predictors of Failure of Noninvasive Positive Pressure Ventilation in Patients with Acute Hypoxemic Respiratory Failure: A Multi-Center Study. Intensive Care Medicine, 27, 1718-1728. https://doi.org/10.1007/s00134-001-1114-4

[28] Ragaller, M. and Richter, T. (2010) Acute Lung Injury and Acute Respiratory Distress Syndrome. Journal of Emergencies, Trauma, and Shock, 3, 43-51. https://doi.org/10.4103/0974-2700.58663 